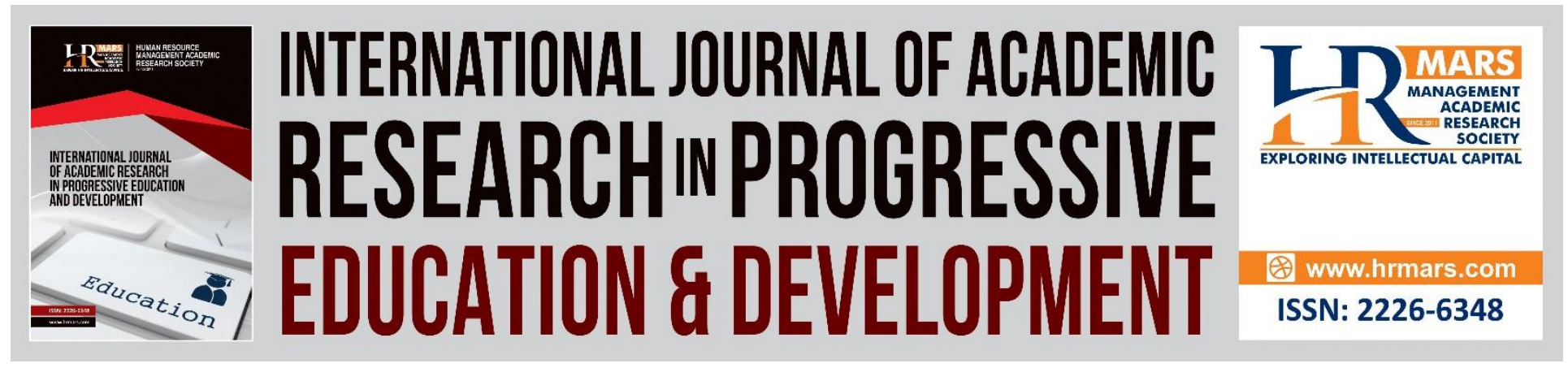

\title{
The Relationship between Multiple Intelligence on the Performance of Arts Stream Students in Linear and Non- Linear MUET Reading Component
}

Nuramirah Zaini

To Link this Article: http://dx.doi.org/10.6007/IJARPED/v7-i4/4837

DOI: $10.6007 /$ IJARPED/v7-i4/4837

Received: 23 Sept 2018, Revised: 28 October 2018, Accepted: 09 Nov 2018

Published Online: 16 Nov 2018

In-Text Citation: (Zaini, 2018)

To Cite this Article: Zaini, N. (2018). The Relationship between Multiple Intelligence on the Performance of Arts Stream Students in Linear and Non-Linear MUET Reading Component. International Journal of Academic Research in Progressive Education and Development, 7(4), 80-94.

Copyright: (c) 2018 The Author(s)

Published by Human Resource Management Academic Research Society (www.hrmars.com)

This article is published under the Creative Commons Attribution (CC BY 4.0) license. Anyone may reproduce, distribute, translate and create derivative works of this article (for both commercial and non-commercial purposes), subject to full attribution to the original publication and authors. The full terms of this license may be seen at: http://creativecommons.org/licences/by/4.0/legalcode

Vol. 7, No. 4, 2018, Pg. 80 - 94

http://hrmars.com/index.php/pages/detail/IJARPED

JOURNAL HOMEPAGE

Full Terms \& Conditions of access and use can be found at http://hrmars.com/index.php/pages/detail/publication-ethics 


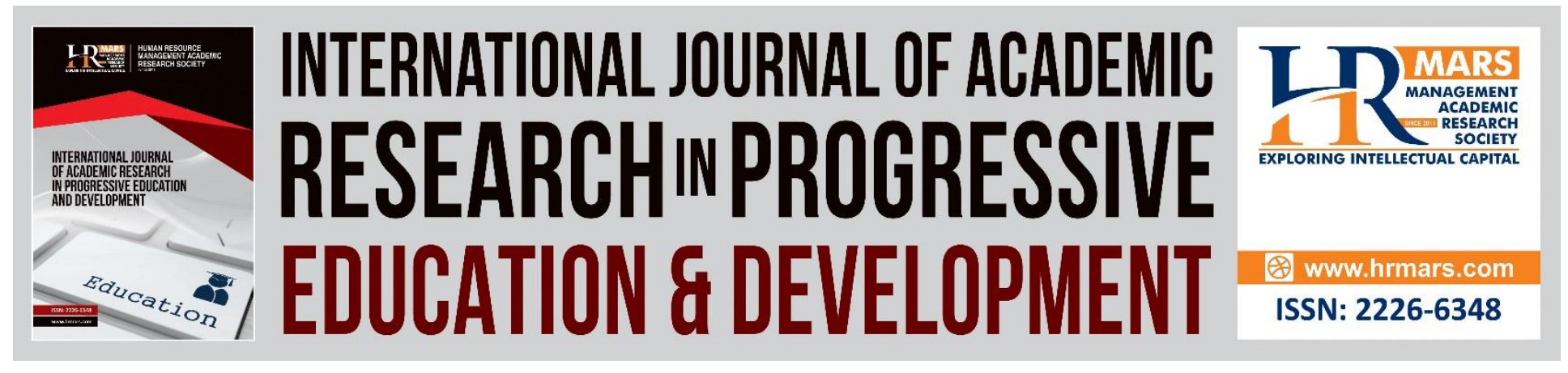

\title{
The Relationship between Multiple Intelligence on the Performance of Arts Stream Students in Linear and Non-Linear MUET Reading Component
}

\author{
Nuramirah Zaini \\ Akademi Pengajian Bahasa Uitm Cawangan Melaka, Kampus Jasin, Malaysia
}

\begin{abstract}
Concerning the fact that reading comprehension is a cognitively complex process, this research attempts to relate Multiple Intelligence which believed to have a role in determining the performance of the learners in different reading texts namely linear and non-linear which involve difference approach in analysing information. In gathering data, the researcher utilized two instruments namely the Reading Component of Malaysian University English Test (MUET) and Multiple Intelligence Questionnaire. Indeed, 60 diploma students studying in UiTM Alor Gajah Melaka were chosen to represent the Arts Stream students. Generally, the findings revealed that Bodily-Kinaesthetic Intelligence has positive relationship with the total score of MUET Reading Component. This will allow for more considerations in planning language lessons for students from Arts Stream.
\end{abstract}

Keywords: English Language Skills, Multiple Intelligence, Linear Text, Non-Linear Text

\section{Introduction}

Learning language requires people to deal with the skills of listening, speaking, writing and reading to be proficient in the language learnt. Undeniably, some language learners tend to do well in a particular skill but not the others, which is believed resulted from the notion of individual's Multiple Intelligence. Multiple Intelligence theory had been developed by Howard Gardener in the early 1980s in which he stated that the traditional notion of intelligence as measured by I.Q testing is far too limited due to the fact that people are different in their different aspect of intelligence that causes differences in people's performance on different tasks ( Gardner, 1983, p.51 cited in Javanmard, 2012, p.61). Indeed, Gardner's 7 autonomous capacities involved in this study are Verbal-Linguistic Intelligence, Logical-Mathematical Intelligence, VisualSpatial Intelligence, Music-Rhythemic Intelligence, Bodily-Kinesthetic Intelligence, Interpersonal Intelligence, and Intrapersonal Intelligence (Hou Yi-an, 2010). 
Vol. 7, No. 4, 2018, E-ISSN: 2226-6348 ๑ 2018 HRMARS

On the other hand, there are two types of texts known as linear and non-linear. Church (2001) has defined linear as a traditional text type that has a topic sentence at the beginning of a paragraph which is followed by several supporting sentences that serves that further elaboration to the topic sentence (cited in Rahman, 2010). Non-linear text indeed has been referred to by Charney (1987), Ain Nadzimah Abdullah \& Chan S.H. (2006) as the opposite of linear texts in which it allows readers to control their own movement in reading; not necessarily front-to-back movement, and text is normally accompanied by graphic-visual representation (cited in Rahman, 2010).

Hence, in regard to the types of reading comprehension tests involving linear and non-linear texts in MUET, it can be argued that Multiple Intelligence might have a role in determining language learners' performance due to the distinct format of the texts that requires different reading strategies. Regardless of the numerous studies on the relation of Multiple Intelligence and performance in language skills conducted, it appears that there is a gap in determining and comparing the relationship of Multiple Intelligence and language learners' performance on both linear and non-linear reading comprehension tests. Therefore, this research focused on the correlation of the two variables and revealed to what extend the prominent type of Multiple Intelligence obtained by learners from Art Stream would significantly predicts their performance on different texts of reading comprehension tests.

\section{Multiple Intelligence Theory and Mental Model}

The Multiple Intelligence Theory proposed by Howard Gardner in 1983 conceives that everyone has varying levels of intelligence which leads to unique cognitive profiles (Karim Hajhashemi, Kourosh Akef \& Neil Anderson, 2012). Thus, the seven intelligences and their explicit implications are explained in brief below.

Verbal-Linguistic Intelligence: This intelligence is defined by Gardner (1993) as sensitivity to the spoken and written language and using the language to achieve goals (cited in Karim Hajhashemi, Kourosh Akef \& Neil Anderson, 2012). It is indeed mentioned by Javanmard (2012), individuals who dominantly categorized in this intelligence have the capacity to use words effectively, whether orally or in writing and they can manipulate the syntax structure of language, the semantics or meanings of language as well as the pragmatic dimensions or practical uses of language.

Logical-Mathematical Intelligence: Individuals with strong Logical Mathematical Intelligence has the capacity to use number effectively and to reason well (Javanmard, 2012). In addition, Armstrong (2003) claimed this intelligence includes the ability to understand and use logical structures including patterns and relationships as well as statements and propositions, through experimentation, quantification, conceptualization and classification (cited in Karim Hajhashemi, Kourosh Akef \& Neil Anderson, 2012).

Visual-Spatial Intelligence: Mckenzie (2009) defines this intelligence as the ability to learn visually and organize ideas spatially as in seeing concepts in action in order to understand them. 
INTERNATIONAL JOURNAL OF ACADEMIC RESEARCH IN PROGRESSIVE EDUCATION AND DEVELOPMENT

Vol. 7, No. 4, 2018, E-ISSN: 2226-6348 ๑ 2018 HRMARS

Indeed, this intelligence involves sensitivity to colour, line, shape, form, space and the relation that exists between these elements (Javanmard, 2012).

Music-Rhythemic Intelligence: It is mentioned in Karim Hajhashemi, Kourosh Akef \& Neil Anderson's (2012) that Lazear (2004) considered this intelligence as the knowing which occurs through hearing, sounds, vibrational patterns, rhythm and tonal patterns, including the full range of potential sounds produced with the vocal chords.

Bodily-Kinesthetic Intelligence: Javanmard (2012) categorized individuals with this intelligence as having the expertise in using their body to express ideas and feelings as in the specific physical skills such as coordination, balance, dexterity, strength, flexibility and speed. In fact, this intelligence allows individuals to learn through interaction and it promotes understanding through concrete experience (Mckenzie, 2009).

Interpersonal Intelligence: It is claimed by Mckenzie (2009) that interpersonal intelligence promotes collaboration and working cooperatively with others in which individuals with this intelligence tends to learn through interaction.

Intrapersonal Intelligence: This intelligence includes the ability to learn through feelings, values and attitudes in a way that individuals place value on what they learn and take ownership for their learning (Mckenzie, 2009).

On the other hand, one of the theories that incorporate reading comprehension process that might affect learner's performance in language learning is Mental Model Theory proposed by Johnson-Laird (1983). In fact, the term Mental Model has been related to many domains and studies and it is believed that Johnson-Laird's (1983) is the most appropriate for this research context as he suggested that mental models can be constructed from perception, imagination, or the comprehension of discourse. According to Johnson-Laird (1983), 'in order to understand their world by comprehending what causes, influence, controls or prevents phenomena, humans construct models of it'. Thus, the process of comprehending discourse in this research context is related to the understanding of Linear and Non-Linear Texts.

\section{Brief Literature on Multiple Intelligence and English Language Skills Studies}

In a study entitled The Relationship between Multiple Intelligences and Reading Proficiency of Iranian EFL Students conducted by Karim Hajhashemi, Kourosh Akef \& Neil Anderson (2012), 128 randomly selected pre-university students have become the respondents of a demographic questionnaire, a Persian version of Mckenzie's Multiple Intelligence Inventory and a standardize reading proficiency test retrieved from paper-based TOEFL tests. The result of this study showed that there was a statistically significant difference in the mean of musical-rhythemic intelligence scores of the low achievers and the high achievers which revealed that high achievers may have lower musical intelligence and vice versa. However, the study which is closely related to this research was conducted towards Iranian EFL students which focuses on standardize reading texts only. Therefore, this research attempted to fit in Malaysian context by distributing instruments to ESL Malaysian learners using both linear and non-linear texts. 
Based on a research carried out by Sharifah Amani Syed Abdul Rahman (2010) entitled The Effects of Linear and Non-Linear Text on Students' Performance in Reading, it has been found out that most respondents favoured and scored better in non-linear questions as compared to linear questions. The research which involved primarily semester one students of UiTM City Campus, Johor Bahru branch required students to respond to a set of surveys as well as linear and nonlinear reading tests besides a number of interview questions. Indeed, the interview exposed four of six respondents chose non-linear text because it could be easily understood and tackled in a short period of time (Sharifah Amani binti Syed Abdul Rahman, 2010). Even though the research done was not related to Multiple Intelligence, it serves as a good reference in evaluating data acquired pertaining to respondents' performance on the linear and non-linear MUET reading comprehension texts.

Another study conducted by Majid Pour-Mohammadi, Mohamad Jafre Zainol Abidin \& Khairul Anuar Bin Yang Ahmad (2012) entitled The Relationship between Students' Strengths in Multiple Intelligences and Their Achievement in Learning English Language has involved secondary school students in Perak, Malaysia. The findings has stated that in a learning environment where multiple intelligences may not be actively used, there is a tendency to have weak and negative correlation between multiple intelligences and English language achievement' (Majid PourMohammadi, Mohamad Jafre Zainol Abidin \& Khairul Anuar Bin Yang Ahmad, 2012). The researchers added that, there are distinct differences in the relationship between the two streams of Science and Art regarding the subjects they take. In addition to that, a study entitled Multiple Intelligence Scores of Science Stream Students and Their Relation with Reading Competency in Malaysian University English Test (MUET) conducted by Norizan Abdul Razak \& Nuramirah Zaini (2014) disclosed the fact that Science stream students' competency in reading skill correlates with their dominant intelligence as the results portrayed positive relationship among Music-Rhythmic, Bodily-kinaesthetic, Visual-spatial and Interpersonal Intelligence with their performance on reading component as a whole as well as in linear and non-linear reading text respectively'. Therefore, concerning the later finding, this research has focused on the Arts Stream students as respondents in gathering data.

\section{Purpose of the Study}

The purpose of this study was to investigate the relationship between two variables known as Multiple Intelligence and Arts Stream students' performance on MUET reading comprehension paper involving linear and non-linear texts as well as to find out the type of Multiple Intelligence that serves as a good predictor on learners' performance in MUET reading comprehension paper. This study was conducted based on the Null Hypotheses which suggested that there is no relationship between types of intelligence and learners' performance on MUET reading component as a whole as well as on different texts in MUET reading component. Indeed, the Null Hypothesis also estimated that the Arts Stream students' prominent type of Multiple Intelligence does not significantly predict their performance on different texts in MUET reading component.

\section{Research Questions}

The present paper aimed to provide answers to these three research questions: 
INTERNATIONAL JOURNAL OF ACADEMIC RESEARCH IN PROGRESSIVE EDUCATION AND DEVELOPMENT

Vol. 7, No. 4, 2018, E-ISSN: 2226-6348 @ 2018 HRMARS

Q1. What is the relationship between types of Intelligence and Arts Stream students' competency in reading test?

Q2. What is the relationship between types of Intelligence and Arts Stream students' performance on linear and non-linear texts in reading?

Q3. To what extent the Arts stream students' Multiple Intelligence significantly predicts their competency on different texts in MUET reading component?

\section{Methodology}

\section{Participants}

In accomplishing the paper, 60 diploma students from Faculty of Art and Design studying in UiTM Alor Gajah Melaka were chosen to represent the Arts Stream. According to Karim Hajhashemi \& Wong Bee Eng (2012), the most important characteristic of a sample is its representiveness of the population under study which should be kept as the major goal in selecting the sample. In this regards, the participants were selected accordingly based on the calculation of sample size in the population of diploma students in their respective faculty in UiTM Alor Gajah, Melaka.

\section{Instrumentation}

The instruments used in this study were MUET reading component as well as a Multiple Intelligence questionnaire. The reading test was selected from Federal Malaysian University English Test Model Papers written by Masy Tang (2010) who has Bachelor in Education of TESL programme. There are six texts in MUET reading component comprises Non-Linear and Linear texts which consist of 45 items in the form of Multiple Choice Question.

A Multiple Intelligence questionnaire was also administered to the participants in this study which is based on Howard Gardner's MI Model (1983) adopted from businessballs.com (2012). There are 35 items in the questionnaire pertaining to the seven Multiple Intelligence proposed by Gardner (1983) in Likert format ranged from 1 (Mostly Disagree) to 4 (Mostly Agree).

\section{Statistical Analysis}

The first and second research questions concerned with the relationship between intelligence preferences and performance of Art Stream students on MUET reading component. Therefore, the correlation between Multiple Intelligence score and MUET reading performance once as a whole and the score on the Linear and Non-Linear format respectively were calculated using Bivariate Pearson-correlation in SPSS 16.0. The third question aimed to find out which intelligence type is the best predictor of Art Stream students' performance on different texts in MUET reading component. In this regard, Multiple Linear Regression Enter Method Output and Stepwise Multiple Regression analysis were run to determine which intelligence type scored by participants in Arts Stream serves as the best predictor in the performance of Linear and NonLinear texts in MUET reading component. 


\section{Findings and Discussion}

This section is divided into three parts which will enclose the result of all three research questions starting by discussing the relationship between types of intelligence and learners' performance on MUET reading component as a whole. The second part will then discuss the relationship between types of intelligence and learners' performance on different texts in MUET reading component followed by the third part which will reveal learners' prominent type of multiple intelligences and their performance on different texts in MUET reading component.

\section{Multiple Intelligences and Learners' Performance on MUET Reading Component}

Table 1 shows that only Bodily-Kinaesthetic Intelligence has positive relationship with the total score of MUET Reading Component. This means that there is a tendency for the Art Stream students to get higher score in MUET Reading component if Bodily-Kinaesthetic Intelligence is higher in a person. Indeed, the other intelligences have low negative correlation with the total score of MUET Reading Component. Therefore, the first research question is still supported and the first null hypothesis is rejected.

Indeed, the findings show an agreement with the findings of a research carried out by Majid PourMohammadi et. al (2012) which stated that in a learning environment where multiple intelligences may not be actively used, there is a tendency to have weak and negative correlation between multiple intelligences and English language achievement'. The fact that the respondents

of the Art Stream involved the students from Art and Design Faculty who mainly deal with 'specific physical skills such as coordination, balance, dexterity, strength, flexibility and speed' (Javanmard, 2012) might be the cause of low negative correlation of the other six intelligences with their performance in reading comprehension except for Bodily-Kinaesthetic. 
INTERNATIONAL JOURNAL OF ACADEMIC RESEARCH IN PROGRESSIVE EDUCATION AND DEVELOPMENT

Vol. 7, No. 4, 2018, E-ISSN: 2226-6348 @ 2018 HRMARS

Table 1: Correlation Analysis of Multiple Intelligence and MUET Reading Total Score

\begin{tabular}{|c|c|c|}
\hline & & Total Score of MUET Reading (\%) \\
\hline \multirow[t]{3}{*}{ Verbal-Linguistic Intelligence } & Pearson Correlation & -.252 \\
\hline & Sig. (2-tailed) & .052 \\
\hline & $\mathrm{N}$ & 60 \\
\hline \multirow{3}{*}{$\begin{array}{l}\text { Logical-Mathematical } \\
\text { Intelligence }\end{array}$} & Pearson Correlation & -.027 \\
\hline & Sig. (2-tailed) & .837 \\
\hline & $\mathrm{N}$ & 60 \\
\hline \multirow[t]{3}{*}{ Music-Rhythmic Intelligence } & Pearson Correlation & -.065 \\
\hline & Sig. (2-tailed) & .622 \\
\hline & $\mathrm{N}$ & 60 \\
\hline \multirow[t]{3}{*}{ Bodily-Kinaesthetic Intelligence } & Pearson Correlation & .132 \\
\hline & Sig. (2-tailed) & .316 \\
\hline & $\mathrm{N}$ & 60 \\
\hline \multirow[t]{3}{*}{ Visual-Spatial Intelligence } & Pearson Correlation & -.146 \\
\hline & Sig. (2-tailed) & .267 \\
\hline & $\mathrm{N}$ & 60 \\
\hline \multirow[t]{3}{*}{ Interpersonal Intelligence } & Pearson Correlation & -.130 \\
\hline & Sig. (2-tailed) & .320 \\
\hline & $\mathrm{N}$ & 60 \\
\hline \multirow[t]{3}{*}{ Intrapersonal Intelligence } & Pearson Correlation & -.079 \\
\hline & Sig. (2-tailed) & .547 \\
\hline & $\mathrm{N}$ & 60 \\
\hline
\end{tabular}

Multiple Intelligences and Learners' Performance on Different Texts in MUET Reading Component 
INTERNATIONAL JOURNAL OF ACADEMIC RESEARCH IN PROGRESSIVE EDUCATION AND DEVELOPMENT

Vol. 7, No. 4, 2018, E-ISSN: 2226-6348 @ 2018 HRMARS

Table 2: Correlation Analysis of Multiple Intelligences and Each Test Score

\begin{tabular}{|c|c|c|c|}
\hline & & $\begin{array}{l}\text { MUET Non-Linear Text } \\
\text { Score (\%) }\end{array}$ & $\begin{array}{l}\text { MUET Linear Text } \\
\text { Score (\%) }\end{array}$ \\
\hline \multirow{3}{*}{$\begin{array}{l}\text { Verbal-Linguistic } \\
\text { Intelligence }\end{array}$} & Pearson Correlation & $-.343^{* *}$ & -.166 \\
\hline & Sig. (2-tailed) & .007 & .206 \\
\hline & $\mathrm{N}$ & 60 & 60 \\
\hline \multirow{3}{*}{$\begin{array}{l}\text { Logical-Mathematical } \\
\text { Intelligence }\end{array}$} & Pearson Correlation & .052 & -.055 \\
\hline & Sig. (2-tailed) & .695 & .675 \\
\hline & $\mathrm{N}$ & 60 & 60 \\
\hline \multirow{3}{*}{$\begin{array}{l}\text { Music-Rhythmic } \\
\text { Intelligence }\end{array}$} & Pearson Correlation & .090 & -.140 \\
\hline & Sig. (2-tailed) & .495 & .287 \\
\hline & $\mathrm{N}$ & 60 & 60 \\
\hline \multirow{3}{*}{$\begin{array}{l}\text { Bodily-Kinaesthetic } \\
\text { Intelligence }\end{array}$} & Pearson Correlation & .225 & .057 \\
\hline & Sig. (2-tailed) & .083 & .664 \\
\hline & $\mathrm{N}$ & 60 & 60 \\
\hline \multirow[t]{3}{*}{ Visual-Spatial Intelligence } & Pearson Correlation & -.249 & -.059 \\
\hline & Sig. (2-tailed) & .055 & .652 \\
\hline & $\mathrm{N}$ & 60 & 60 \\
\hline \multirow[t]{3}{*}{ Interpersonal Intelligence } & Pearson Correlation & -.154 & -.057 \\
\hline & Sig. (2-tailed) & .240 & .663 \\
\hline & $\mathrm{N}$ & 60 & 60 \\
\hline \multirow[t]{3}{*}{ Intrapersonal Intelligence } & Pearson Correlation & -.068 & -.055 \\
\hline & Sig. (2-tailed) & .603 & .678 \\
\hline & $\mathrm{N}$ & 60 & 60 \\
\hline
\end{tabular}

As the table shows, all type of intelligences correlate negatively with MUET Linear Text score except for Bodily-Kinaesthetic Intelligence. On the other hand, the data for MUET Non-Linear Text revealed that Logical-Mathematical, Music-Rhythmic and Bodily-Kinaesthetic correlate positively with the score. Indeed, in terms of the significance of the result, it can be seen that all seven Multiple Intelligences and MUET Linear Text score are not statistically significant among the Art Stream students. However, it has been revealed that Verbal-Linguistic Intelligence shows the closest significant data with the Arts Stream students' score in MUET Non-Linear Text. Since both of the Linear and Non-Linear Text scores prove to have positive correlation with some of the Multiple Intelligence, the second research question is still supported and null hypothesis is rejected. 
INTERNATIONAL JOURNAL OF ACADEMIC RESEARCH IN PROGRESSIVE EDUCATION AND DEVELOPMENT

Vol. 7, No. 4, 2018, E-ISSN: 2226-6348 @ 2018 HRMARS

Learners' Prominent Type of Multiple Intelligences as the Predictor of their Performance on Different Texts in MUET Reading Component

In order to find the students' prominent type of Multiple Intelligence that significantly predicts their performance on different text in MUET reading component, a Multiple Linear Regression Analysis and Stepwise Multiple Regression were performed. Overall, in referring to Table 3, the $R$ value shows low degree of correlation between Multiple Intelligence and MUET Reading score as a whole with only $7.9 \%$.

Table 3: Model Summary of Multiple Regression Analysis

(Dependent variable: Total Score of MUET Reading Component)

Model Summary
\begin{tabular}{|l|l|l|l|l|}
\hline Model & R & R Square & $\begin{array}{l}\text { Adjusted R } \\
\text { Square }\end{array}$ & $\begin{array}{l}\text { Std. Error of } \\
\text { the Estimate }\end{array}$ \\
\hline 1 & $.281^{\mathrm{a}}$ & .079 & -.075 & 10.18974 \\
\hline
\end{tabular}

With the aim of finding the most related intelligence on the performance of the Art Stream students on the Linear and Non-Linear texts in MUET Reading component respectively, multiple regression analyses were run for both texts as dependent variables. Table 4, 5 and 6 indicate the results. 
INTERNATIONAL JOURNAL OF ACADEMIC RESEARCH IN PROGRESSIVE EDUCATION AND DEVELOPMENT

Vol. 7, No. 4, 2018, E-ISSN: 2226-6348 C 2018 HRMARS

Table 4: Multiple Regression Analysis of related variables in Linear Text Performance

\section{Coefficients $^{\mathrm{a}}$}

\begin{tabular}{|c|c|c|c|c|c|c|}
\hline \multirow{2}{*}{\multicolumn{2}{|c|}{ Model }} & \multicolumn{2}{|c|}{$\begin{array}{l}\text { Unstandardized } \\
\text { Coefficients }\end{array}$} & \multirow{2}{*}{\begin{tabular}{|l}
$\begin{array}{l}\text { Standardized } \\
\text { Coefficients }\end{array}$ \\
Beta \\
\end{tabular}} & \multirow[b]{2}{*}{$t$} & \multirow[b]{2}{*}{ Sig. } \\
\hline & & $B$ & Std. Error & & & \\
\hline \multirow[t]{8}{*}{1} & (Constant) & 79.510 & 16.014 & & 4.965 & .000 \\
\hline & $\begin{array}{l}\text { Verbal-Linguistic } \\
\text { Intelligence }\end{array}$ & -.535 & .651 & -.131 & -.821 & .415 \\
\hline & $\begin{array}{l}\text { Logical-Mathematical } \\
\text { Intelligence }\end{array}$ & -.143 & .514 & -.038 & -.278 & .782 \\
\hline & $\begin{array}{l}\text { Music-Rhythemic } \\
\text { Intelligence }\end{array}$ & -.669 & .776 & -.133 & -.862 & .393 \\
\hline & $\begin{array}{l}\text { Bodily-Kinesthetic } \\
\text { Intelligence }\end{array}$ & .590 & .620 & .152 & .951 & .346 \\
\hline & $\begin{array}{l}\text { Visual-Spatial } \\
\text { Intelligence }\end{array}$ & -.095 & .718 & -.020 & -.132 & .895 \\
\hline & $\begin{array}{l}\text { Interpersonal } \\
\text { Intelligence }\end{array}$ & -.180 & .806 & -.039 & -.224 & .824 \\
\hline & $\begin{array}{l}\text { Intrapersonal } \\
\text { Intelligence }\end{array}$ & -.230 & .670 & -.053 & -.343 & .733 \\
\hline
\end{tabular}

a. Dependent Variable: MUET Linear Text Score (\%)

The result in Table 4 shows that all independent variables coefficients are not statistically significance in predicting the performance of Art Stream students on MUET Linear text in the reading component.

Table 5: Multiple Regression Analysis (Stepwise) of related variables in Non-Linear Text Performance

\section{Coefficients $^{\mathrm{a}}$}

\begin{tabular}{|c|c|c|c|c|c|c|}
\hline \multirow{2}{*}{\multicolumn{2}{|c|}{ Model }} & \multicolumn{2}{|c|}{$\begin{array}{l}\text { Unstandardized } \\
\text { Coefficients }\end{array}$} & \multirow{2}{*}{\begin{tabular}{|l}
$\begin{array}{l}\text { Standardized } \\
\text { Coefficients }\end{array}$ \\
Beta
\end{tabular}} & \multirow[b]{2}{*}{$\mathrm{t}$} & \multirow[b]{2}{*}{ Sig. } \\
\hline & & $B$ & Std. Error & & & \\
\hline \multirow[t]{2}{*}{1} & (Constant) & 94.323 & 6.976 & & 13.522 & .000 \\
\hline & $\begin{array}{l}\text { Verbal-Linguistic } \\
\text { Intelligence }\end{array}$ & -1.251 & .502 & -.338 & -2.491 & .016 \\
\hline
\end{tabular}

a. Dependent Variable: MUET Non-Linear Text Score (\%) 


\begin{tabular}{|c|c|c|c|c|c|c|}
\hline \multirow{2}{*}{\multicolumn{2}{|c|}{ Model }} & \multicolumn{2}{|c|}{$\begin{array}{l}\text { Unstandardized } \\
\text { Coefficients }\end{array}$} & \multirow{2}{*}{\begin{tabular}{|l} 
Standardized \\
Coefficients
\end{tabular}} & \multirow[b]{2}{*}{$\mathrm{t}$} & \multirow[b]{2}{*}{ Sig. } \\
\hline & & B & Std. Error & & & \\
\hline \multirow[t]{8}{*}{1} & (Constant) & 89.758 & 14.668 & & 6.119 & .000 \\
\hline & $\begin{array}{l}\text { Verbal-Linguistic } \\
\text { Intelligence }\end{array}$ & -1.461 & .597 & -.338 & -2.449 & .018 \\
\hline & $\begin{array}{l}\text { Logical-Mathematical } \\
\text { Intelligence }\end{array}$ & .225 & .471 & .057 & .478 & .635 \\
\hline & $\begin{array}{l}\text { Music-Rhythemic } \\
\text { Intelligence }\end{array}$ & .659 & .711 & .124 & .927 & .358 \\
\hline & $\begin{array}{l}\text { Bodily-Kinesthetic } \\
\text { Intelligence }\end{array}$ & 1.414 & .568 & .346 & 2.490 & .016 \\
\hline & $\begin{array}{l}\text { Visual-Spatial } \\
\text { Intelligence }\end{array}$ & -1.323 & .657 & -.265 & -2.012 & .049 \\
\hline & $\begin{array}{l}\text { Interpersonal } \\
\text { Intelligence }\end{array}$ & -.320 & .738 & -.065 & -.434 & .666 \\
\hline & $\begin{array}{l}\text { Intrapersonal } \\
\text { Intelligence }\end{array}$ & -.412 & .614 & -.090 & -.671 & .505 \\
\hline
\end{tabular}

a. Dependent Variable: MUET Non-Linear Text Score (\%)

Table 6: Multiple Regression Analysis of related variables in Non-Linear Text Performance

On the other hand, Table 5 and 6 which reported the Multiple Regression Analysis of Multiple Intelligence and the performance of Art Stream students on the Non-Linear Text has revealed Verbal-Linguistic Intelligence as the strongest predictor on the performance of the students in this type of text in the MUET reading component. It is indicated that for one standard deviation of change in Verbal-Linguistic Intelligence score, there will be -.338 of a standard deviation change in the Art stream students' performance in Non-Linear text of MUET reading comprehension. Therefore, the third research question is accepted and null hypothesis is rejected.

\section{Conclusion}

In essence, numerous studies on Multiple Intelligences and language learning revealed the significant difference in certain aspects as in learning styles and learning skills. Even though Multiple Intelligence Theory is used by many researches on learning skills including reading, most of the studies were carried out involving students from other countries and none of them engaged both linear and non-linear texts with the MI theory in a paper. 
Vol. 7, No. 4, 2018, E-ISSN: 2226-6348 @ 2018 HRMARS

In this study, the focus was examining the relationship between Multiple Intelligence and the Art stream students' performance on different texts namely Linear and Non-Linear in MUET reading component. The findings of the study have brought several implications of Multiple Intelligence pertaining to the reading proficiency of Art Stream students. Indeed, the most surprising finding of this study is the role of Verbal-Linguistic as the strongest predictor on the students' score in the Non-Linear text which diverted to the estimation of the Logical-Mathematical Intelligence's influence in that sense. However, based on findings of this study, it can be argued that there may be other factors that play a role in reading skills as in individual difference other than their intelligence preference.

Therefore, this research is hoped to contribute to a better understanding of learners' attainment in learning language specifically in reading skills which leads the educators to provide sufficient and suitable input for the learners to be able to cater their individual preferences. Apart from that, it is also vital on the learners' part to know their intelligence type as they can work on the weaknesses for a better performance in language learning as well as to prepare for the Malaysian University English Test (MUET) that comprises both types of reading texts in the reading comprehension paper. The findings of this research are not only beneficial for learners in Art Streams but also contribute to a great understanding on the educators' part to prepare language lessons effectively.

\section{Acknowledgment}

I would like to acknowledge and extend my warmest thanks to all participants from Faculty of Art and Design studying in UiTM Alor Gajah Melaka for their willingness to take part in this study. My gratitude also goes to all people who involved directly or indirectly in assisting the completion of this research. 
INTERNATIONAL JOURNAL OF ACADEMIC RESEARCH IN PROGRESSIVE EDUCATION AND DEVELOPMENT

Vol. 7, No. 4, 2018, E-ISSN: 2226-6348 @ 2018 HRMARS

\section{References}

Javanmard, Y. (2012). On the Relationship Between Multiple Intelligences and Their Performance on Vocabulary Tests among Iranian EFL Learners. Global Journal of Human Social Science, 61.

Johnson-Laird, P. N. (1983). Mental Models: Towards a Cognitive Science of Language, Inference, and Consciousness. United States: Librarary of Congress Cataloging in Publication Data.

Karim Hajhashemi, W. B. (2012). MI as a Predictor of Students' Performance in Reading Competency. English Language Teaching, Vol 5, No.3 242.

Karim Hajhashemi \& Wong Bee Eng. (2012). MI as a Predictor of Students' Performance in Reading Competency. English Language Teaching, Vol 5 (3), 240-253.

Karim Hajhashemi, Kourosh Akef \& Neil Anderson. (2012). The Relationship between Multiple Intelligences and Reading Proficiency of Iranian EFL Students. World Applied Sciences Journal, 19(10) 1475-1483.

Magisterska, P. (2001). Application of Computer Assissted Language Learning in the Development of Reading Comprehension Skills. Retrieved on October 4, 2013 from http://wa.amu.edu.pl/wa/files/ifa/papers/kledecka/kledecka-mgr.pdf

Majid Pour-Mohammadi, Mohamad Jafre Zainol Abidin \& Khairul Anuar Bin Yang Ahmad (2012). The Relationship between Students' Strengths in Multiple Intelligences and Their Achievement in Learning English Language. Journal of Language Teaching and Research, Vol 3 (4), 677-686

Mckenzie, W. (2009). Walking the Walk: Multiple Intelligences in Educator Professional Development. Massachusetts Computer Using Educators. Retrieved on October 4, 2013 from http://surfaquarium.com/Walk_the_Walk.pdf

Multiple Intelligence Test. (2012). Retrieved from Howard Gardner's Multiple Intelligences: http://www.businessballs.com/howardgardnermultipleintelligences.htm

Norizan Abdul Razak \& Nuramirah Zaini. (2014). Multiple Intelligence Scores of Science Stream Students and Their Relation with Reading Competency in Malaysian University English Test (MUET). English Language Teaching, 63-72.

Rahman, S. A. (2010). The Effects of Linear and Non-linear texts on Students' Performance in Reading.

Tang, M. (2010). Federal Malaysian University English Test Model Papers. Selangor: 
INTERNATIONAL JOURNAL OF ACADEMIC RESEARCH IN PROGRESSIVE EDUCATION AND DEVELOPMENT

Vol. 7, No. 4, 2018, E-ISSN: 2226-6348 @ 2018 HRMARS Marshall Cavendish.

Yi-an, H. (2010). Multiple Intelligences and Foreign Language Learning- A Case Study in Taiwan. WHAMPOA- An Interdiscplinary Journal , 1. 